\title{
Doktori filozofije iz znanstvenog područja povijesti na Filozofskom fakultetu Sveučilišta u Zagrebu do 1945. godine
}

\author{
Pregledni rad \\ Review article \\ UDK 378.4(497.5 Zagreb).096.1:<378.22:94
}

\begin{abstract}
Autor donosi popis osoba koje su na Filozofskom fakultetu u Zagrebu doktorirale povijest kao glavnu struku, od početka moderne sveučilišne povijesti do kraja Drugoga svjetskog rata. Uvodno je naveo osnovne informacije o načinu kako se u to doba doktoriralo. Uz imena doktora i naslove disertacija, autor je dao i najvažnije biografske podatke o doktorima, među kojima su i najznačajnija imena hrvatske historiografije 20. stoljeća, ali i neke posve anonimne osobe koje nisu ostavile nikakav trag u povijesnoj znanosti niti neki veći trag na polju nastave ili druge javne djelatnosti.
\end{abstract}

Ključne riječi: doktorat, disertacija, historiografija, Filozofski fakultet, Sveučilište u Zagrebu

$\mathrm{D}$ anas su doktorati znanosti, koji se stječu na završetku poslijediplomskog doktorskog studija, mnogima važno ishodišno mjesto buduće znanstvene karijere. Ne mora značiti vrhunac, nego je mnogo češće tek početak bavljenja znanošću. Uglavnom se radi ubrzano, tijekom nekoliko godina nakon završetka diplomskoga studija i stjecanja stručne profesionalne kvalifikacije. Doktorandi su pritisnuti rokovima u kojima moraju završiti svoj poslijediplomski studij, napisati i obraniti radnju. Ranije je bilo drukčije. Nakon Drugoga svjetskog rata, osobito tijekom pedesetih, šezdesetih i sedamdesetih, djelomice i osamdesetih, disertacija se smatrala krunom znanstveno-istraživačkoga rada. Velikom je broju povjesničara upravo disertacija, i na temelju toga priređena knjiga, bila i ostala najvažnije djelo u cijeloj znanstvenoj karijeri. Na disertaciji iz povijesnih znanosti radilo se u to doba, sve do zadnjega desetljeća dvadesetoga stoljeća, dugo i temeljito, bila je opsežna i utemeljena na istraživanjima arhivske građe iz niza arhiva i biblioteka, a postupak obrane znao se otegnuti i po godinu dana, pa i dulje. Osobe koje su branile takve disertacije bile su već u zrelim srednjim godinama, istraživački formirane, i disertacija je predstavljala potvrdu njihova znanstvenog digniteta i ozbiljnosti. Naravno, mogla se ponekad zadesiti i neka manje važna disertacija, ali od pedesetih do devedesetih godina, radilo se uglavnom o važnim temama hrvatske historiografije. Osobe koje su stekle doktorate znanosti obično su postigle i znamenite znanstveno-istraživačke i nastavne karijere.

U dva sam teksta dao popise i kratke analize tematike disertacija iz povijesti od 1946. do 2008. te od 2009. do 2012. godine. (Agičić 2009; 2013) U posljednjih se nekoliko godina 
povećao broj studija na kojima se mogu steći doktorati, a tendencija povećanja broja mjesta doktoriranja se nastavlja. Još je uočljiviji trend porasta obranjenih doktorata, odnosno broja doktora znanosti iz polja povijesti. Dok su u šezdesetak godina na dva studija povijesti doktorate stekla 204 kandidata, u samo četiri godine doktorsku su titulu iz polja povijesti dobile čak 122 osobe. Mnogi od njih u statusu su znanstvenih novaka, pa već i po prirodi stvari aspiriraju na znanstvene karijere. Baza hrvatske historiografije, dakle, snažno se povećava. U skoroj ćemo budućnosti vidjeti kakvi će biti rezultati te velike produkcije doktora povijesti.

Moderno sveučilište u Zagrebu, koje je započelo s radom u jesen 1874., vrlo je brzo počelo izdavati doktorske titule. Već su prvi propisi i uredbe bili rađeni po uzoru na ostala austrijska sveučilišta. Od samoga su se početka dodjeljivali doktorati prava, bogoslovlja i filozofije - potonji su se mogli steći nakon četverogodišnjeg studija na filozofskome fakultetu (u Zagrebu ili drugdje u Austro-Ugarskoj), polaganja strogih ispita (rigoroza) i prihvaćanja disertacije. Prema Redu strogih izpitah na fakultetu mudroslovnom kr. sveučilišta Franje Josipa I. u Zagrebu, disertacija se pisala na hrvatskom ili latinskom: „Razpravom ima kandidat dokazati, da je vješt znanstvenoj metodi svoje struke, da je vrstan samostalnim sudom u njoj raditi i napredovati, i da si je usvojio način razpravljanja toj struci dolikujući." Disertacija je trebala biti dovoljno dobra da može biti tiskana, a predavala se isprva u tri primjerka. (Kritovac 1976a: 22) Nekim je kasnijim nadopunama bilo određeno da se prije promocije na čast doktora mora predati 50 tiskanih primjeraka disertacije, što je vrijedilo do 1911. godine kada je uveden propis o predaji samo četiri ili čak samo jednog primjerka disertacije ako se radilo o opsežnijem radu. Nakon promjena zakonskih propisa 1931. prije dobivanja diplome „doktora filozofije“ moralo se predati 100 tiskanih primjeraka disertacije, ali su mnogi doktorati rađeni na temelju starih propisa pa se ova odredba mogla izbjeći. Promijenjena je tek 1948. godine, kada je uvedena odredba da disertacija mora predstavljati samostalan prilog znanosti, da treba „predstavljati samostalan rad u čijem je rezultatu dato rješenje ili teoretsko obrazloženje naučnih problema, ili su naučno predstavljeni novi problemi koji imaju interes za nauku“. Dubravka Kritovac ističe da je za disertacije do 1911. bila karakteristična visoka kvaliteta jer su tiskane kao monografije ili članci u znanstvenim časopisima, a neke i „danas predstavljaju doprinos znanstvenoj i kulturnoj baštini“. S druge strane, disertacije nakon 1911. nisu više bile dobro opremljene, sadržaj im je znao biti manje kvalitetan, a mnoge su i zauvijek izgubljene jer su se predavale samo u pisanoj, ne u tiskanoj formi (Kritovac 1976a: 24-25, 30, 36).

Stroge ispite, odnosno rigoroze iz filozofije morali su sve do uredbe o doktorskim ispitima iz 1928. polagati svi kandidati za stupanj „doktora filozofije“, a drugi je strogi ispit bio iz jedne od struka koje su se predavale na filozofskom fakultetu, među kojima je od početka bila povijest (uz latinsku i grčku filologiju kao dodatnu struku). Kasnije je lista strukovnih rigoroza proširena na više znanstvenih polja, među kojima i na hrvatsku povijest s općom povijesti. (Opća povijest bila je dodatna struka i drugim osnovnim strukama, primjerice slavistici, hrvatskoj filologiji i povijesti hrvatske književnosti, geografiji, povijesti umjetnosti. $U$ analizi koja slijedi nisu uzimani doktori kojima je povijest bila dodatna struka, nego samo glavna.)

Strogi ispiti bili su javni, a polagali su se sve do zakonskih promjena nakon Drugoga svjetskog rata. Tijekom postupka obrane doktorata i polaganja strogih ispita disertacija se posebno ocjenjivala. Bilo je moguće i da izvjestitelji traže ispravke prije konačne predaje u tisak, što se događalo s nekim disertacijama iz povijesti.

Osim na Filozofskom fakultetu u međuratnom su se razdoblju doktorati s povijesnom tematikom mogli steći i na Ekonomsko-komercijalnoj visokoj školi u Zagrebu. Radilo se o temama iz diplomatske i političke povijesti modernog, odnosno suvremenog razdoblja. Između 1927. i 1932. obranjeno je 15 takvih disertacija. (Kritovac 1976b: 182-185) Radilo se 
uglavnom o autorima koji se kasnije nisu bavili znanstvenim niti nastavnim radom na polju historijske znanosti te njihova imena ne znače ništa u razvoju historiografije.

U članku donosim kronološki popis s imenima doktora filozofije u znanstvenom području povijesti, naslovima njihovih disertacija i datumima obrane doktorskih ispita na Filozofskom fakultetu Sveučilišta u Zagrebu. U popis su uključeni podaci koje sam pronašao u matičnim knjigama doktora, odnosno u različitim enciklopedijskim i leksikonskim natuknicama ili pak tekstovima o onima koji su ostavili neki trag u historiografiji ili nekom drugom polju djelatnosti. Uglavnom se radi o nekrolozima ili pak prigodnim obljetničkim tekstovima. Nisu se svi doktori u to doba nastavili baviti znanstvenim radom, mnogi od njih bili su gimnazijski profesori. Nažalost, o velikom broju nisu zabilježeni tragovi o datumu i mjestu smrti. Vrlo su korisna u pripremi biografskih podataka bila izdanja Leksikografskog zavoda "Miroslav Krleža" u Zagrebu, napose Hrvatski biografski leksikon i Hrvatska enciklopedija (dostupna na internetu - www.enciklopedija.hr), kao i Enciklopedija srpske istoriografije, koju je uredio Sima Ćirković (objavljena u Beogradu 1998). Osim već navedene bibliografije Dubravke Kritovac, postoje još dva popisa doktorskih disertacija, onaj Blaža Jurišića „Doktorske disertacije hrvatskoga sveučilišta Mudroslovnog fakulteta", Nastavni vjesnik, 39/1930-1931, 80-87 te Ivana Kurjaka „Doktorirali na Filozofskome fakultetu“, Filozofski fakultet Sveučilišta u Zagrebu (ur. S. Damjanović), Zagreb 1998, 325-358.

Prvi je doktorat u struci povijesti iz 1886., odnosno 1889. (kada se računa datum polaganja obveznog strogog ispita iz filozofije kao datum promocije), a posljednji iz 1944. godine. U nešto više od pola stoljeća na čast doktora filozofije (u polju povijesti) na Filozofskom fakultetu Sveučilišta u Zagrebu promovirana je četrdeset i jedna osoba, među njima i dvije žene - Milica Bogdanović i Marija Rafaela Grašovec.

Oko polovine disertacija bilo je posvećeno srednjovjekovnoj povijesti, desetak in se bavilo problematikom ranoga novog vijeka, a po tri su bile o antičkom razdoblju odnosno modernoj povijesti. Nekoliko je disertacija obuhvaćalo dulje vremensko razdoblje, odnosno bile su posvećene problematici teorije historije ili povijesti historiografije. lako je prva disertacija obranjena na zagrebačkom Sveučilištu, ona Gjure Arnolda, u naslovu imala riječ „povijest“ (Etika i povijest), to nije bila povijesna nego filozofska rasprava. Arnold je kasnije ostvario karijeru sveučilišnog profesora filozofije. Teorijska disertacija M. Pollaka (Problemi spoznajne teorije povijesne nauke) nije se sačuvala. Jaroslav Šidak napisao je prvu povijesnohistoriografsku disertaciju; govorio je o problematici Crkve bosanske u dotadašnjoj historiografiji.

Prva osoba koja je stekla doktorat iz polja povijesti bio je Dane Gruber (Senj, 1856. - Zagreb, 1927.), kasniji profesor Filozofskog fakulteta Sveučilišta u Zagrebu. Inače, on je bio u prvoj generaciji studenata tog fakulteta, između 1874. i 1878., kada je diplomirao povijest i geografiju. Doktorski ispit iz hrvatske te svietske poviesti položio je 15. svibnja 1886., a kandidat je „jednoglasno osposobljen“. Njegovu su pisanu disertaciju pod naslovom Vojevanje Ljudevita I. u Dalmaciji sa hrvatskimi velmožami i sa Mletčani od početka njegovoga vladanja do osamgodišnjega primirja sa Mletčani (1342-1348) Natko Nodilo i Tadija Smičiklas prihvatili 30. rujna 1886., uz napomenu da se radnja «ima prema naputku prije promocije preraditi». Drugi strogi ispit, iz filozofije kao drugoga predmeta, polagao je prvi put 8. listopada 1887., ali ga nije položio. Tom je ispitu drugi put pristupio 26. ožujka 1889. i položio ga s dovoljnom ocjenom, a dan kasnije predao je i pedeset otisaka svoje pisane disertacije. Dakle, Gruber je doktorat stekao u postupku koji je trajao skoro tri godine, od svibnja 1886. do kraja ožujka 1889. godine.

Drugi je doktorski ispit na povijesti 13. srpnja 1891. polagao Josip Modestin pred dekanom Đurom Pilarom te profesorima Smičiklasom i Nodilom. Prema matičnoj knjizi 
doktora, Modestinu je hrvatska historija bila glavni, a opća sporedni predmet. Ispit je položio s odličnom ocjenom, a predao je i pedeset primjeraka disertacije Kritička potraživanja $i$ pokušaj pragmatizovanja u poviesti dubrovačke od 1205 do 1331 god. Doktorski je postupak završio 13. lipnja 1892. polaganjem ispita iz filozofije s ocjenom dovoljan. Modestin se kasnije nije bavio povijesnim istraživanjima. Radio je kao gimnazijski profesor u Vinkovcima i Sušaku, povremeno surađivao u Nastavnom vjesniku te bio autor geografskih priručnika i udžbenika.

O trećem doktoru povijesti, Sandoru Szentgyörgiju, nisam pronašao nikakve relevantne podatke, osim onoga što stoji u matičnoj knjizi doktora. Doktorski ispit iz hrvatske povijesti uz svjetsku povijest položio je 6. travnja 1893. „jednoglasno s odlikom“, predao pedeset primjeraka disertacije Borba Anžuvinaca oko prestolja hrvatsko ugarske za pošljednjih Arpadovaca, a potom je 14. srpnja 1893. položio s dovoljnim uspjehom ispit iz filozofije.

Rudolf Horvat (Koprivnica, 14. ožujka 1873. - Zagreb, 25. svibnja 1947.) doktorski ispit iz hrvatske uz opću povijest položio je s odličnom ocjenom 23. prosinca 1897. Njegova je doktorska radnja bila Kralj Tomislav i njegovo doba. No, niti Horvat nije blistao na doktorskom ispitu iz filozofije (historije filozofije i etike) - položio ga je 15. travnja 1898. većinom glasova s ocjenom dovoljan. Kasnije je Horvat postigao znamenitu karijeru gimnazijskog profesora, istraživača i popularizatora na polju historiografije, autora brojnih knjiga i članaka iz hrvatske povijesti te na kraju i sveučilišnog profesora tijekom Drugoga svjetskog rata. Nakon rata bio je optužen za suradnju s ustaškim režimom i osuđen na dugogodišnji gubitak političkih i građanskih prava. Bavio se i politikom, jedan je od osnivača Hrvatske pučke seljačke stranke, kao i Hrvatskog radiše.

Peti doktorat iz povijesti na Sveučilištu Franje Josipa I., kako se u to doba zvala zagrebačka univerza, stekao je Ferdo Šišić (Vinkovci, 9. ožujka 1869. - Zagreb, 21. siječnja 1940.), jedan od najvećih hrvatskih povjesničara 20. stoljeća. Doktorski ispit iz hrvatske i opće povijesti obranio je 4. srpnja 1899. s ocjenom odličan. Šišić je napisao doktorsku radnju Zadar i Venecija od 1159-1247. Ni on nije blistao na doktorskom rigorozu iz filozofije, koji je branio 18. prosinca 1900. - ocijenjen je s dovoljnim. Isprva gimnazijski profesor u Gospiću, Osijeku i Zagrebu, privatni docent (1902.), izvanredni (1906.) i od 1909. redoviti profesor Filozofskog fakulteta te član JAZU-a od 1910. godine, bio je aktivan u političkom životu, saborski zastupnik Hrvatsko-srpske koalicije i član delegacije na Mirovnoj konferenciji u Parizu. Imao je snažan utjecaj u hrvatskoj historiografiji, napose u medievistici, ali i istraživanjima moderne i suvremene povijesti; jedan je od utemeljitelja i voditelja povijesnog društva u međuratnoj Jugoslaviji te urednik hrvatske redakcije Jugoslovenskog istorijskog časopisa.

Josip Bösendorfer (Lukač, Virovitica, 30. siječnja 1876. - Osijek, 6. lipnja 1957.) doktorski ispit iz hrvatske i opće povijesti položio je 22. srpnja 1899. Komisija mu je dala prolaznu dovoljnu ocjenu, a kandidatova je rasprava bila naslovljena Zavjera Petra Šubića Zrinjskoga, bana hrvatskoga (1664-1671). Ispit iz filozofije Bösendorfer nije položio odmah, nego iz drugoga pokušaja 23. srpnja 1902. - tada je dobio ocjenu „odličan“. Radio kao gimnazijski profesor u Zagrebu i Osijeku, gdje je bio i ravnatelj gimnazije. Nakon prijevremenog umirovljenja djelovao u Društvu prijatelja starine u Osijeku; organizirao Gradski muzej i bio njegovim ravnateljem do 1949. Pokretač je i urednik Osječkog zbornika. Bavio se najviše crkvenom poviješću, ali i drugim temama, osobito iz povijesti gospodarstva. Priredio je i objavio velik izbor arhivske građe, prije svega o Osijeku i Slavoniji.

Odlične ocjene na oba rigoroza, i onome iz hrvatske i opće povijesti i onome iz filozofije, dobili su dvojica sljedećih doktora, kasnije sveučilišnih profesora u Zagrebu.

Karlo Horvat (Križevci, 22. rujna 1874. - Zagreb, 24. rujna 1920.) doktorski ispit iz povijesti položio je 20. srpnja 1900., a radnju je napisao pod naslovom Toma grof Erdedi. 
Doktorski ispit iz filozofije položio je 17. prosinca 1900. Horvat je prvo bio završio Bogoslovni fakultet (1897), a potom studirao povijest i geografiju u Zagrebu i Beču, a kasnije se usavršavao u paleografiji u Rimu i dr. Bavio se prvenstveno hrvatskom poviješću 16-17. st., a od 1908. profesor je Filozofskog fakulteta u Zagrebu. Dopisni je član JAZU-a od 1911. (Časopis Povijesnog društva Križevci Cris, br. 3/2001. posvećen je Karlu Horvatu; radi se o izlaganjima na kolokviju koje je to društvo organiziralo u suradnji s Odsjekom za povijest Filozofskog fakulteta u Zagrebu; tamo se nalazi nekoliko tekstova koji osvjetljavaju različite aspekte njegova života i djelovanja - usp. http://hrcak.srce.hr/index.php?show=toc\&id_ broj=6649 - posjet 1 . ožujka 2014.)

Milan Šufflay (Lepoglava, 9. studenoga 1879. - Zagreb, 19. veljače 1931.) doktorski ispit polagao je 12. srpnja 1901., a njegova je radnja bila naslovljena Hrvatska i zadnja pregnuća iztočne imperije pod žezlom triju Komnena. Doktorski ispit iz filozofije dao je 17. prosinca 1901. Potom je nastavio usavršavanje u Beču, a od 1904. radio je kao kustos u Narodnom muzeju u Budimpešti. Od 1908. prvi je profesor pomoćnih povijesnih znanosti na Filozofskom fakultetu u Zagrebu. Zbog svojih stavova i političke djelatnosti u međuratnoj Jugoslaviji progonjen je i zatvaran, a na kraju i ubijen u atentatu što su ga organizirale režimske strukture. Jedan je od utemeljitelja albanistike, priznat i cijenjen u međunarodnim znanstvenim krugovima. Osim znanstvenih radova, pisao je političke eseje i romane.

Bogoljub Krnic (Kostajnica, 25. svibnja 1874. - Zagreb, 5. veljače 1918.) doktorski je ispit iz hrvatske uz opću povijest položio 15. listopada 1906, a napisao je raspravu pod naslovom Opći sud (iudicium generale) u Ugarskoj i Hrvatskoj. Ispit iz filozofije položio je s odličnim uspjehom 28. svibnja 1907. Bavio se prvenstveno pravno-povijesnom tematikom. Radio je kao gimnazijski profesor u Zagrebu i arhivar JAZU-a, a kratko je vrijeme na zagrebačkom sveučilištu bio privatni docent na katedri opće povijesti, gdje je pokrivao povijest 16-17. stoljeća.

Nikola Radojčić (Kuzmin, Slavonija, 29. kolovoza 1882. - Beograd, 12. studenoga 1964.) doktorski je ispit položio iz opće povijesti s grčkom filologijom, a njegovu su raspravu Dva posljednja Komnena na carigradskom carskom prijestolu ocijenili profesori Vjekoslav Klaić i Gavro Manojlović. Rigoroz iz filozofije Radojčić je položio 28. svibnja 1907. s odličnom ocjenom. Isprva je radio kao gimnazijski profesor, a nakon Prvoga svjetskog rata postavljen je za profesora Sveučilišta u Ljubljani. Godine 1941. prešao u Beograd, gdje je uoči kraja rata dobio profesorsko mjesto na Sveučilištu, ali je 1945. umirovljen. Bio je redoviti član SAN-a (od 1938.) pod čijim je okriljem nastavio znanstvenu djelatnost do smrti. Bavio se bizantološkim temama, srpskom pravnom poviješću i srednjovjekovnom poviješću Bosne.

Milica Bogdanović (Linz, 29. ožujka 1882. - Beograd, 2. veljače 1973.) bila je prva žena koja je doktorirala povijest. Ona je prvo položila doktorski ispit iz psihologije i povijesti filozofije, 10. veljače 1906., a doktorski ispit iz svjetske povijesti i latinskoga položila je s odličnim uspjehom 14. lipnja 1907. na temelju disertacije Car Julijan Apostat prema kršćanstvu. Radila je kao gimnazijska profesorica, odnosno profesorica Više pedagoške škole u Zagrebu. Tijekom Drugoga svjetskog rata preselila se i potom ostala živjeti u Beogradu, jedno vrijeme u Srijemskim Karlovcima. Djelovala je kao spisateljica i prevoditeljica, socijalna aktivistica te bila jedna od vodećih hrvatskih intelektualki u međuraću.

Petar Karlić (Gospić, 19. studenoga 1877. - Zagreb, 24. travnja 1940.) doktorski je ispit iz hrvatske povijesti kao glavne, a opće kao „popunjujuće“ struke položio 2. travnja 1910. Njegovu su disertaciju Izbor i krunisanje Vladislava kralja češkoga za kralja ugarskoga i hrvatskoga odobrili Smičiklas i Manojlović. Ispit iz filozofije, također s odličnom ocjenom, položio je 29. srpnja 1911. godine. Radio je kao gimnazijski profesor u Zadru i Zagrebu te Državnom arhivu u Zagrebu, a jedno je vrijeme bio i privatni docent na Filozofskom fakultetu 
(1921-1926) i honorarni docent na Višoj pedagoškoj školi u Zagrebu (od 1926). Bavio se proučavanjem povijesti narodne dinastije i hrvatskih kraljeva, kao i razdobljem francuske uprave u Dalmaciji te književnom poviješću, a napisao je i studiju o svome mentoru Vjekoslavu Klaiću. Bio je aktivan u upravi Matice dalmatinske te predsjednik Društva hrvatskih srednjoškolskih profesora.

Josip Hartinger (Würbenthall, Šleska, 16. kolovoza 1884. - ?, svibanj 1945.) doktorirao je hrvatsku i opću povijest, položivši ispit 8. veljače 1911. s odličnim uspjehom pred povjerenstvom koji su činili dekan Kazimir Grekša, profesori Vjekoslav Klaić i Ferdo Šišić. Njegova je disertacija naslovljena Hrvatsko-slovenska seljačka buna g. 1573. Rigoroz iz filozofije položio je 14. srpnja 1911. godine. Radio je kao gimnazijski profesor u Osijeku i Zagrebu, odnosno kao profesor Trgovačke akademije u Osijeku. Osim povijesti i geografije, predavao je i njemački jezik. Od 1940. bio je ravnatelj Prve ženske realne gimnazije u Zagrebu. Nakon uspostave NDH-a priklonio se ustaškom režimu, pa su ga partizani odveli u nepoznatom pravcu odmah po ulasku u Zagreb u svibnju 1945. godine.

Grga Novak (Hvar, 2. travnja 1888. - Zagreb, 7. rujna 1978.) s odličnim je uspjehom 27. listopada 1913. položio doktorski ispit iz povijesti i geografije, a njegovoj su disertaciji Slaveni i Venecija oba ocjenitelja, Klaić i Šišić, dali tek dovoljnu ocjenu. Na rigorozu iz filozofije 31. listopada 1913., Novak je zaslužio ocjenu dobar. Bio je gimnazijski profesor u Splitu te suradnik i pomoćnik Frana Bulića u splitskom arheološkom muzeju. Sveučilišnu karijeru započeo u Skopju, od 1924. profesor je Sveučilišta u Zagrebu, a nakon Drugoga svjetskog rata član i dugogodišnji predsjednik JAZU-a, odnosno počasni predsjednik. Bio je jedan od najznačajnijih hrvatskih arheologa i povjesničara stare povijesti; napose je poznat po radovima o grčkoj i rimskoj kulturi na Jadranu te povijesti dalmatinskih gradova.

Fra Pero Ćubela (Grgurići, Livno, 27. rujna 1885. - ?) položio je 26. veljače 1914. doktorski ispit iz historije srednjega i novoga vijeka i geografije s ocjenom dobar. Prihvaćena je njegova disertacija O nutarnjemu stanju kršćana u Bosni za XVI. stoljeća. Ispit iz filozofije Ćubela je položio 21. ožujka 1914. te time stekao doktorsku titulu.

Viktor Novak (Stubica, 4. veljače 1889. - Beograd, 1. siječnja 1977.) položio je 3. srpnja 1915. doktorski ispit iz hrvatske historije s pomoćnim znanostima (paleografijom i diplomatikom) kao glavnom, a arheologijom kao drugom strukom. Novakovu su disertaciju Mikac Mihaljević i njegovo doba od 1325-1343. s odličnom ocjenom ocijenili profesori Šišić i Karlo Horvat. Strogi ispit iz filozofije Novak je položio 10. srpnja 1916. godine, s odličnim uspjehom. Radio kao gimnazijski profesor, potom u Sveučilišnoj knjižnici u Zagrebu, od 1920. je docent/profesor pomoćnih povijesnih znanosti na Sveučilištu u Zagrebu, od 1924. na beogradskom Sveučilištu uz te predmete predaje i srednjovjekovnu te hrvatsku povijest. Bavio se također modernom i suvremenom poviješću; osobito je poznat po djelu Magnum crimen. Pola vijeka klerikalizma u Hrvatskoj iz 1948., zbog kojega je izopćen iz Katoličke crkve.

Radoslav Grujić (Zemun, 29. lipnja 1878. - Hvar, 25. svibnja 1955.) doktorirao je 14. srpnja 1919. hrvatsku povijest i geografiju položivši s odličnim uspjehom ispit. Njegova je disertacija naslovljena Građa za kulturnu istoriju Slavonije. Ispit iz filozofije položio je 31. srpnja 1919. godine. Bio je gimnazijski profesor u Bjelovaru i Beogradu, potom sveučilišni profesor narodne historije na Filozofskom fakultetu u Skopju (gdje je bio i dekan) te osnivač Skopskog naučnog društva, a od 1937. redoviti je profesor na Bogoslovskom fakultetu u Beogradu. Nakon rata izložen progonima, izbačen je sa Sveučilišta i gubi građanska prava. Rehabilitiran je 2014. Bavio se poviješću Srpske pravoslavne crkve te školstva i kulturne povijesti.

Miroslav Pollak (Požega, 19. ožujka 1898. - ?) položio je jednosatni ispit iz opće povijesti 20. srpnja 1921., a dvosatni rigoroz iz filozofije položio je godinu dana kasnije, 3. srpnja 
1922. Njegova je disertacija naslovljena Problemi spoznaje teorije povijesne nauke. Prema podacima Istraživačkog i dokumentacijskog centra za žrtve i preživjele Holokausta u Židovskoj općini u Zagrebu, preživio je rat, ali nisam pronašao nikakve druge podatke. (www.cendo. hr-posjet 3. ožujka 2014.)

Nikola Ćorić (Varcar Vakuf, BiH, 16. veljače 1883. - ?) dvosatni je ispit iz "hrvatske povijesti kao glavne struke, a geografije kao nadopune" položio 5. travnja 1924. Dok je na ispitu dobio ocjenu odličan, njegova je rasprava Grad Kotor u vlasti bosanskih kraljeva od 1385. do 1420. bila ocijenjena ocjenom dobar. Jednosatni je rigoroz iz filozofije položio 27. lipnja 1925. s odličnim uspjehom. Radio je kao gimnazijski profesor u Osijeku, a nakon uspostave Banovine Hrvatske postao je ravnateljem tamošnje gimnazije. (http://www. gimnazija-treca-os.skole.hr/povijest/ - posjet 3. ožujka 2014.)

Nikola Maslać (D. Hrasno, BiH, 19. veljače 1895. - Zagreb, 20. srpnja 1969.) doktorski je ispit iz hrvatske povijesti i geografije položio 1. listopada 1924. s ocjenom dovoljan. Njegovu su disertaciju Pape i Hrvati za provala turskih na Balkan (1360-1464) Šišić i Milan Prelog ocijenili ocjenom dobar. S dovoljnim je uspjehom Maslać zadovoljio na rigorozu iz filozofije 13. listopada 1924. godine. Studirao je teologiju u Rimu i Sarajevu, a zaređen je 1927. Gimnazijski profesor u Travniku, nakon rata profesor na Visokoj bogoslovnoj školi u Sarajevu, a onda župnik u Uzdolu te gimnazijski profesor u Dubrovniku. Prevodio je s talijanskog i njemačkog. U međuraću objavljuje dvije knjige - jednu pod naslovom Čeh, Leh i Meh : hrvatska poviest od najstarijih do najnovijih vremena te Pregled opće povijesti srednjega i novoga vijeka (za narod). (www.uzdol.com / posjet 25. veljače 2014.)

S. Marija Rafaela Grašovec (Đurđevac, 23. veljače 1892. - Argentina, 29. lipnja 1963.) jednosatni je strogi ispit iz „domaće historije“ položila 15. listopada 1924. s ocjenom dobar. Njezinu su disertaciju Problem volje u savremenoj pedagogici s dobrim ocijenili profesori Stjepan Matičević i Albert Bazala. Dvosatni je rigoroz iz filozofije i pedagogije položila 28. siječnja 1926. godine. Nije se bavila znanstvenim radom, nego djelovala u sklopu Družbe sestara milosrdnica sv. Vinka Paulskoga. U misiji u Argentini bila je između 1952. i 1957. U toj je južnoameričkoj zemlji i preminula (usp. http://misije.milosrdnice.hr/dodatno/popispreminulih-sestara-koje-su-djelovale-u-juznoj-americi/ - posjet 25. veljače 2014.).

Nikola Lalić (Sarajevo, 26. kolovoza 1901. - ?) polagao je dvosatni rigoroz iz opće historije i geografije 23. listopada 1925. Ispit, kao i disertacija Ruski socijalni pokreti, ocijenjeni su s odličnim. Jednosatni ispit iz filozofije položio je s dobrim uspjehom 27. listopada 1925. godine. Kao student bio je prvi predsjednik studentskog društva Klub slušača historije, koji je osnovan 1925. godine.

Josip Špoljar (Pakrac, 3. veljače 1888. - ?) položio je 30. listopada 1925. dvosatni rigoroz iz hrvatske historije, opće historije i geografije $s$ ocjenom dovoljan. $\mathrm{S}$ istom su ocjenom njegovu ispravljenu disertaciju Povijest Pakraca od najstarijih vremena do osvojenja pod Turcima ocijenili profesori Šišić i Prelog. Ispit iz filozofije položio je 27. studenog 1926. godine.

Josip Cinotti (Šibenik, 20. siječnja 1902. - ?) doktorirao je 1. veljače 1926. povijest i geografiju s ocjenom dovoljan. Njegova je disertacija Knez Krsto Frankopan i njegovo doba ocijenjena s dobrim. Ispit iz filozofije položio je s dovoljnim 5. prosinca 1930. godine.

Zvonimir Dugački (Osijek, 1. siječnja 1903. - Zagreb, 19. siječnja 1974.) doktorski ispit iz domaće i opće historije s geografijom položio je 26. listopada 1927. s odličnom ocjenom, a za disertaciju Knez Ivaniš Nelipčić dobio je istu ocjenu od ocjenitelja Šišića i Grge Novaka. S istim je uspjehom 26. ožujka 1928. obranio ispit iz filozofije. Karijeru je izgradio na području geografije, kao gimnazijski profesor u Karlovcu, Sušaku i Varaždinu, kao profesor Ekonomskokomercijalne visoke škole i potom Filozofskog fakulteta u Zagrebu. Nakon rata protjeran sa 
Sveučilišta, predavao je u Nadbiskupskoj klasičnoj gimnaziji u Zagrebu. Kao glavni urednik poduzeća "Učila“ od 1949., dao je snažan doprinos razvoju školske kartografije u Hrvatskoj.

Nikola Kalogjera (Blato, 20. prosinca 1889. - ?) doktorirao je 6. prosinca 1927. „domaću“ i opću historiju s geografijom s odličnim uspjehom. Njegova je disertacija bila Bratovštine $i$ obrtne udruge u Splitu. Ispit iz filozofije također je položio s odličnim uspjehom 14. veljače 1928. godine.

Vladimir Mošin (Petrograd, 9. listopada 1894. - Skopje, 3. veljače 1987.) položio je 7. veljače 1928. dvosatni ispit iz opće historije srednjega vijeka sa slavenskim starinama. Ispit je ocijenjen s dovoljan, jednako kao i pisana radnja Tmutorokanjska Rusija. Ocjenu dobar dobio je iz ispita iz filozofije, koji je položio 2. lipnja 1928. godine. Radio je kao gimnazijski profesor u Koprivnici, sveučilišni docent u Skopju, pa u Beogradu, gdje je tijekom rata umirovljen, ali je djelovao kao pravoslavni svećenik i profesor rusko-srpske gimnazije. Nakon rata bio je direktor Arhiva JAZU-a i v. d. direktora Historijskog instituta JAZU-a; kad se kandidirao za direktora, pod nejasnim je okolnostima ponovno umirovljen. Potom je radio kao redoviti honorarni profesor sveučilišta u Beogradu te Filozofskog fakulteta u Skopju. Pružio je golem doprinos na području bizantologije i slavistike te bio član mnogih znanstvenih društava i dopisni član Makedonske akademije nauka. (Greškom je izostavljen u popisu doktora u monografiji Filozofski fakultet Sveučilišta u Zagrebu, ur. S. Damjanović, Zagreb 1998.) / (Vladimir Aleksejevič Mošin, Pod teretom. Autobiografija, Prijevod i komentari Nesiba Palibrk-Sukić, Pančevo, 2008.)

Vlaho Kojaković (Čibač, 7. listopada 1900. - Dubrovnik, 29. siječnja 1981.) položio je 5. lipnja 1928. dvosatni doktorski ispit iz narodne i opće historije s geografijom. Dobio je ocjenu dobar, a njegova je disertacija Dubrovnik zadnjih decenija prije velikoga potresa 6. aprila god. 1667. bila ocijenjena s odličnim. Ispit iz filozofije položio je 27. lipnja 1928. godine. Radio je kao gimnazijski profesor u Dubrovniku, jedan je od osnivača i aktivista Društva prijatelja dubrovačke starine, vanjski suradnik Historijskog instituta JAZU-a, autor članaka u Analima, u časopisu Dubrovnik i dr.

Josip Klemenc (Ljubljana, 4. ožujka 1898. - Ljubljana, 28. rujna 1967.) doktorirao je 25. travnja 1929. grčku i rimsku povijest u vezi s klasičnom arheologijom. Disertacija Dislokacija rimske vojske u Panoniji u prvom stoljeću po Is. ocijenjena je dovoljnom ocjenom. Ispit iz filozofije položio je 27. lipnja 1929. godine. Isprva je radio kao gimnazijski profesor u Ptuju i Celju, potom kao asistent i kustos Arheološkog muzeja u Zagrebu. Od 1946. do smrti predavao je na Filozofskom fakultetu u Ljubljani.

Juraj Kolaković (Priboj, Plitvička jezera, 8. travnja 1905. - Zagreb, 3. srpnja 1975.) doktorski ispit iz hrvatske povijesti i geografije položio je 25. svibnja 1929. Dobio je odličnu ocjenu, kao i za disertaciju Obrana Siska 1591.-1593., koju su ocijenili Šišić i Hauptmann. Rigoroz iz filozofije položio je s dobrim uspjehom 26. lipnja 1929. godine. Radio je kao gimnazijski profesor u Bihaću, Bjelovaru (gdje je bio i direktor) i Zagrebu, bio je urednik časopisa Historijski pregled. Od 1961. predavao je opću povijest novog vijeka na Filozofskom fakultetu u Zadru te povijest političkih ideja na Visokoj upravnoj školi, odnosno na Pravnom fakultetu u Zagrebu.

Mihovio Barada (Seget, 16. ožujka 1889. - Zagreb, 9. srpnja 1957.) doktorirao je 29. svibnja 1929. hrvatsku povijest i geografiju položivši ispit. U postupku je napisao disertaciju Topografija Porfirogenitove Paganije, koju su Šišić i Hauptmann ocijenili s odličnim. Rigoroz iz filozofije Barada je položio s dovoljnim 15. listopada 1929. godine. Nastavio se baviti znanstvenim i nastavnim radom - bio je profesor crkvene povijesti na Bogoslovnom fakultetu od 1932., a potom je 1940. naslijedio Šišića na mjestu profesora hrvatske povijesti na Filozofskom fakultetu. Proučavao hrvatsku ranosrednjovjekovnu povijest, osobito pravnu 
problematiku i povijest plemstva. Urednik časopisa Croatica sacra (1935-1941). Do 1927. radio je kao svećenik u Dalmatinskoj zagori i Trogiru.

Stjepan Leander Deduš (Bikovac, 4. veljače 1898. - ?) doktorski ispit iz grčke i rimske povijesti te geografije položio je 26. studenoga 1931. s dovoljnim. Istu je ocjenu dobio za disertaciju Politika perzijskog satrapa Tisaferna, a s dovoljnim je zadovoljio i rigoroz iz filozofije 27. veljače 1932. godine.

Milan Starčević (Gospić, 15. rujna 1904. - ?) položio je 9. travnja 1932. strogi ispit u području „narodna povijest (hrvatska povijest u redu strogih ispita) i geografija“ s ocjenom dobar. Njegova disertacija Postanak hrvatske stranke prava god. 1861. ocijenjena istom ocjenom, kao i ispit iz filozofije položen 3. studenog 1932. godine.

Držislav Švob (Karlovac, 5. svibnja 1907. - Lepoglava, travanj 1945.) doktorski ispit iz hrvatske povijesti i geografije položio je s odličnom ocjenom 10. veljače 1933. Njegovu su disertaciju Komes Domald Šišić i G. Novak ocijenili s dobrim. Ispit iz filozofije Švob je položio 29. lipnja 1933. godine. Radio je kao kustos u Hrvatskom narodnom muzeju i potom kao upravitelj Hrvatskoga povijesnog muzeja, a od 1943. izvanredni je profesor Filozofskog fakulteta u Zagrebu. Ustaške vlasti uhitile su ga 1944. pod optužbom za suradnju s Narodnooslobodilačkim pokretom te je bio osuđen na smrt. Pomilovan je, a kazna mu je preinačena u doživotni zatvor. Prebačen je u Lepoglavu i pod nerazjašnjenim okolnostima ubijen potkraj rata.

Lovre Katić (Solin, 8. veljače 1887. - Solin, 27. kolovoza 1961.) položio je doktorski ispit iz narodne historije 18. svibnja 1933. s „odlikom“. Njegova je disertacija bila naslovljena Saksonac Gottschalk na dvoru kneza Trpimira. On je ispit polagao po novoj uredbi iz 1928. godine te nije morao polagati zaseban ispit iz filozofije jer je $u$ ispitnom povjerenstvu bio $i$ profesor filozofije. Radio je kao gimnazijski profesor u Sinju, Kninu i Splitu, u vrijeme rata direktor gimnazije u Zagrebu, od 1942. profesor je na Visokoj pedagoškoj školi. Od 1945. muzejski je ravnatelj, konzervator i znanstvenik u Splitu te profesor tamošnje Visoke bogoslovne škole (1948-1956). Proučavao je srednjovjekovnu povijest, napose crkvenu i kulturnu, kao i povijest arheologije.

fra Fabijan Paponja (Lipno kod Ljubuškog, BiH, 26. studenoga 1897. - ?, 7/8. veljače 1945.) dvosatni je rigoroz iz hrvatske povijesti i geografije položio 29. lipnja 1933. s odličnim uspjehom. Disertacija Borba protiv reforama i pacifikacija Hercegovine za Omer-paše Latasa bila je ocijenjena s ocjenom dobar. Ispit iz filozofije položio je 4. srpnja 1933. Od 1927, kada je završio studij povijesti i geografije na Sveučilištu u Ljubljani, predavao je te predmete u gimnaziji u Širokom Brijegu, gdje je bio i ravnatelj konvikta. Tragično je stradao na početku veljače 1945. kad su partizani odveli grupu franjevaca u nepoznatom smjeru i pogubili ih.

Vinko Foretić (Korčula, 2. kolovoza 1901. - Dubrovnik, 17. srpnja 1986.) položio je 27. lipnja 1935. dvosatni doktorski ispit iz historije i geografije. Ocjena je bila odličan, kao i za disertaciju Povijest Korčule do g. 1420. Ispit iz filozofije položio je s istom ocjenom 21. veljače 1936. Radio je kao gimnazijski profesor između 1925. i 1941. te arhivist u Državnom arhivu u Dubrovniku do umirovljenja 1973.: pružio je velik doprinos sređivanju arhiva i uređivanju građe. Autor je niza radova o povijesti Dubrovnika i hrvatske povijesti srednjeg i ranog novog vijeka.

Jaroslav Šidak (Beč, 4. siječnja 1903. - Zagreb, 25. ožujka 1986.) doktorski je ispit položio 30. listopada 1935. s odličnim uspjehom. Njegova je disertacija bila Problem „Bosanske Crkve“ u našoj historiografiji od Petranovića do Glušca / Prilog rješenju tzv. "bogomilskog pitanja". $\mathrm{U}$ to je doba radio kao gimnazijski profesor u Senju, a kasnije je prešao u Hrvatski izdavalački bibliografski zavod. Od 1943. do umirovljenja bio je profesor na Filozofskom fakultetu u Zagrebu. Ostavio je golem trag u historiografiji kao jedan od pokretača i dugogodišnji glavni 
urednik Historijskog zbornika te učitelj i mentor mnogim povjesničarima u drugoj polovici 20. stoljeća.

Stjepan Antoljak (Doboj, BiH, 29. kolovoza 1909. - Zagreb, 2. rujna 1997.) doktorski ispit položio je 19. prosinca 1935. Ocijenjen je s ocjenom zadovoljava, jednako kao i za disertaciju Dalmacija i Venecija na preliminarima u Leobenu i na miru u Campo-Formiju. Od 1934. do 1946. asistent je, odnosno docent na Filozofskom fakultetu u Zagrebu, 1946-1952. direktor Državnog arhiva u Zadru, potom je radio u Državnom arhivu u Rijeci, a od 1956. redoviti je profesor Filozofskog fakulteta u Skopju, Prištini i napokon u Zadru (1969-1979). Pružio je značajan doprinos razvoju hrvatske, makedonske i kosovarske albanske historiografije. Napose je velik njegov doprinos enciklopedistici i leksikografiji.

Evgenije Valdec (Sisak, 30. rujna 1906. - ?) s vrlodobrim je uspjehom doktorirao 20. prosinca 1941. Njegova je radnja Hrvatska u doba bune Franje II. Rákóczya ocijenjena s dobar.

Zlatko Tanodi (Breznički Hum, 1. rujna 1914. - Córdoba, Argentina, 14. srpnja 2011.) doktorirao je 11. studenog 1944. s odličnim uspjehom. Njegova je disertacija bila naslovljena Zagrebačka "Zlatna bula". Od 1937. radio je u Gradskom arhivu u Varaždinu, od 1940. u Državnom arhivu u Zagrebu. Godine 1944. imenovan je za docenta na katedri za pomoćne povijesne znanosti Filozofskog fakulteta u Zagrebu. U političkoj je emigraciji nakon 1945, isprva u Austriji i Italiji, gdje se dalje školuje. Od 1948. u Argentini, gdje je zaslužan za utemeljenje moderne arhivske službe; bio je direktor Argentinskog državnog arhiva (19591986), osnivač katedre za paleografiju i diplomatiku na sveučilištu u Córdobi.

Još je nekoliko doktora koji su svoje disertacije izradili o povijesno-geografskim temama, a doktorski su ispit polagali na XIII. studijskoj grupi, odnosno antropogeografiji. Neki od njih kasnije su se bavili povijesnim, arheološkim i drugim istraživanjima, poput Stjepana Gunjače.

Nikola Peršić doktorski ispit iz antropogeografije položio je 26. listopada 1935. obranivši disertaciju Prirast i kretanje gradskog stanovništva s naročitim obzirom na grad Zagreb. Obrana je bila prema uredbi iz 1928. godine.

Stjepan Gunjača (Sinj, 28. rujna 1909. - Split, 6. prosinca 1981.) doktorirao je antropogeografiju 24. studenoga 1937., a disertaciju je pisao na temu Topografska razmatranja na teritoriju stare cetinske županije s ekskursima o ubikaciji Petovije i Tiluriuma.

Aron Fleischman (Vinkovci, 7. listopada 1910. - ?) doktorirao je 17. studenoga 1932. antropogeografsku grupu obranivši disertaciju Razvitak grada Zagreba od najstarijih vremena do danas. Ocjena je bila dovoljan, odnosno zadovoljava.

Dragan Zbožinek (Palešnik, Hercegovac, 10. listopada 1907. - ? 1983.) doktorirao je antropogeografiju 14. travnja 1932., obranivši disertaciju Antropogeografija srednje Slavonije s odličnim uspjehom. Rigoroz iz filozofije položio je u drugom pokušaju 5. svibnja 1933. godine. Kasnije je bio asistent na Sveučilištu i bavio se etnološkim istraživanjima.

Josip Šalomon (Đelekovec 26. veljače 1914. - ?) doktorirao je 11. studenoga 1944. s dobrim uspjehom. Disertaciju je napisao pod naslovom Novčana sila Hrvatske u XVI. st. (1526.-1606.).

U matičnim knjigama doktora zabilježeno je i nekoliko imena onih koji su položili doktorski ispit iz povijesti, ali nisu položili rigoroz iz filozofije, pa tako nisu stekli uvjete za priznavanje doktorata. Pronašao sam podatke o troje takvih osoba: Marko Tugomir Petričević (nema podataka o mjestu i datumu rođenja) doktorski je ispit iz hrvatske i opće historije položio s dovoljnim uspjehom 11. srpnja 1892. godine. Petar Komnenić (Pilatovac, 16. studenoga 1895. - ?) doktorski ispit položio je s dovoljnim 7. studenoga 1930. nakon 
prihvaćanja disertacije Hercegovački ustanak (1861.-1862.). Dvaput je pao na rigorozu iz filozofije (10. siječnja 1931. i 11. travnja 1931.). Emilija Muža (nema podataka o mjestu i datumu rođenja) doktorski je ispit iz hrvatske povijesti i arheologije položila s odličnom ocjenom 4. veljače 1922. Njezina je disertacija bila naslovljena Petar Keglević, ban hrvatski (1537-1542), a ocijenjena je s dobrim. Rigoroz iz filozofije nije položila.

Filozofski fakultet Sveučilišta u Zagrebu ima skoro stoljeće i pol dugu tradiciju obrazovanja povjesničara - već od samoga početka rada modernog sveučilišta postojale su dvije povijesne katedre: za opću povijest i za hrvatsku povijest s osobitim obzirom na austrijsku i ugarsku povijest. Kasnije, od početka 20. stoljeća, počela je djelovati i katedra za pomoćne povijesne znanosti. Postupno se povećavao broj profesora i (isprva privatnih) docenata, a kasnije i asistenata na fakultetu. Naravno, ta su se mjesta popunjavala iz redova doktora koji su svoje titule stekli upravo na Filozofskom fakultetu. Neki od doktora povijesti koji su doktorirali u Zagrebu kasnije su postigli karijeru u drugim sveučilišnim centrima Jugoslavije, a neki i u inozemstvu. Budući da je broj profesorskih mjesta na sveučilištu bio u to doba vrlo ograničen, mnogi su doktori radili kao gimnazijski profesori ili stručnjaci u muzejima, arhivima i drugim institucijama. To im nije smetalo da budu aktivni u znanstvenom životu, dapače, mnogi su s dosta žara i entuzijazma pisali i objavljivali radove. Velik broj doktora nastavio je raditi u promijenjenim političkim okolnostima i nakon Prvoga i nakon Drugoga svjetskog rata. No bilo je i onih koji su u tom radu onemogućavani, politički progonjeni i suđeni; neki su od njih tragično završili svoje živote, dok su drugi spas pronašli u političkoj emigraciji.

\section{POPIS LITERATURE}

\section{AGIČIĆ 2009}

Damir Agičić, „Doktorati iz povijesti u Hrvatskoj nakon Drugoga svjetskog rata (1946-2008). Prilog istraživanju historije historijske znanosti“, u: Spomenica Josipa Adamčeka, FF Press, Zagreb 2009, 519-537.

\section{AGIČIĆ 2013}

Damir Agičić, „Doktorati iz povijesti u Hrvatskoj 2009-2012. godine", Historijski zbornik, LXVI/2013, br. 2, 421-441.

\section{KRITOVAC 1976A}

Dubravka Kritovac, Razvoj doktorata znanosti na Sveučilištu u Zagrebu: historijat - propisi
- bibliografija (1874-1974), magistarski rad, Prirodoslovno-matematički fakultet, Centar za studij bibliotekarstva, dokumentacije i informacijskih znanosti, Zagreb 1976.

\section{KRITOVAC 1976B}

Dubravka Kritovac (prir.), Bibliografija doktorskih disertacija 1880-1952, Referalni centar, Zagreb 1976.

NAJBAR-AGIČIĆ 2013

Magdalena Najbar-Agičić, U skladu s marksizmom ili činjenicama. Hrvatska historiografija 1945-1960., Ibis grafika, Zagreb 2013. 


\section{SAŽETAK}

Moderno sveučilište u Zagrebu brzo je počelo izdavati doktorske titule po uzoru na ostala austrijska sveučilišta. Dodjeljivali su se doktorati prava, bogoslovlja i filozofije. Filozofski fakultet Sveučilišta u Zagrebu ima skoro stoljeće i pol dugu tradiciju obrazovanja povjesničara - od 1874. postojale su dvije povijesne katedre: za opću povijest i za hrvatsku povijest s osobitim obzirom na austrijsku i ugarsku povijest, a od početka 20. stoljeća i katedra za pomoćne povijesne znanosti. Prvi je doktorat iz povijesti bio stečen 1889 . godine. Do 1944. povijest je doktorirala ukupno 41 osoba, među njima dvije žene. Od njih su se regrutirali profesori Filozofskog fakulteta u Zagrebu, a neki od tih doktora postigli su karijere i u drugim sveučilišnim centrima Jugoslavije, a neki i u inozemstvu. Budući da je broj profesorskih mjesta na sveučilištu bio u to doba vrlo ograničen, mnogi su doktori radili kao gimnazijski profesori ili stručnjaci u muzejima, arhivima i drugim institucijama. Bili su dosta aktivni u znanstvenom životu te su pisali i objavljivali radove. Velik broj doktora nastavio je raditi nakon Prvoga i nakon Drugoga svjetskog rata, ali je bilo i onih koji su u tom radu onemogućavani; neki su od njih tragično završili svoje živote, dok su drugi spas pronašli u političkoj emigraciji.

\section{SUMMARY}

\section{Doctors of Philosophy in the Scientific Area of History at the Faculty of Humanities and Social Sciences of the University of Zagreb until 1945}

The modern university in Zagreb promptly issuing the doctorate titles like other Austrian universities. There were doctorates in law, religion science and philosophy. The Philosophical Faculty of the University of Zagreb has an almost century and a half long tradition of education of historians - since 1874, there were two departments of history: for general history and for Croatian history with special regard for Austrian and Hungarian history; since the beginning of 20th century, there was also the department of auxiliary historical sciences. The first history doctorate was issued in 1889. Until 1944, there were 41 doctorates of history, two women among them. Among these, the professors of the Philosophical Faculty in Zagreb were recruited, and some of these doctors have made careers in other university centers of Yugoslavia, or even abroad. Since the number of tenures at the university was very limited at the time, many doctors worked as gymnasium teachers or experts in museums, archives and other institutions. They were quite active in scientific area, and they wrote and published papers. A substantial number of doctors continued to work after the First and Second World War, but there were those whose work was canceled; some of them ended their lives tragically, while others were forced to migrate and seek asylum in other countries.

Keywords: doctorate, dissertation, historiography, Philosophical Faculty, University of Zagreb 